\title{
PENGARUH DEBT TO EQUITY RATIO (DER) DAN EARNING PER SHARE (EPS) TERHADAP HARGA SAHAM (STUDI KASUS PADA PERUSAHAAN SUB SEKTOR PERTAMBANGAN BATUBARA YANG TERDAFTAR DI BURSA EFEK INDONESIA PERIODE TAHUN 2014 - 2019)
}

\author{
Putri Asri Budiyani, \\ Fakultas Ekonomi, Universitas Singaperbangsa \\ Karawang \\ putri.asri16220@ student.unsika.ac.id ${ }^{1}$
}

\author{
Dailibas $^{2}$ \\ Fakultas Ekonomi, Universitas Singaperbangsa \\ Karawang \\ dailibas@fe.unsika.ac.id ${ }^{2}$
}

\begin{abstract}
Abstrak
Perkembangan perusahaan subsektor pertambangan batubara mengalami penurunan terutama pada harga saham. Kinerja perusahaan menjadi titik utama bagi para investor untuk menanamkan modal di tengah level kurang yang baik dengan dipengaruhi berbagai faktor, di antaranya karena faktor hutang dan laba. Laporan keuangan adalah salah satu pembuktian dari kinerja perusahaan. Pencarian faktor-faktor tersebut dilakukan dengan menganalisis rasio keuangan yang berhubungan dengan hutang dan laba. Tujuan penelitian ini adalah menganalisis apakah DER dan EPS berpengaruh secara parsial dan bersama-sama terhadap harga saham. Populasi dalam penelitian ini adalah seluruh perusahaan subsektor pertambangan batubara yang terdaftar pada Bursa Efek Indonesia periode 2014 - 2019 dengan sampel sebanyak 10 perusahaan. Penelitian ini bersifat kuantitatif dengan teknik purposive sampling. Data yang digunakan adalah laporan keuangan yang dipublikasikan Bursa Efek Indonesia kemudian diolah menggunakan SPSS for Windows 25. Penelitian memperoleh hasil bahwa secara parsial DER tidak berpengaruh terhadap harga saham sedangkan EPS berpengaruh terhadap harga saham. Sedangkan secara simultan DER dan EPS berpengaruh secara bersamasama terhadap harga saham. Berdasarkan hasil model regresi, DER dan EPS memiliki pengaruh yang kuat terhadap harga saham dengan determinasi sebesar 37\%. Pengaruh terbesar disumbangkan EPS sebesar 31\% kemudian DER sebesar 6\%.
\end{abstract}

Kata Kunci: DER, EPS, Harga Saham 


\section{PENDAHULUAN}

Pasar modal dan sekuritas menjadi alat untuk investasi keuangan yang berperan dalam perkembangan dunia ekonomi. Kebutuhan informasi dalam mengambil keputusan menjadi hal utama yang diperlukan untuk mencari gambaran suatu perusahaan. Laporan keuangan adalah salah satu informasi yang mudah didapat kemudian digunakan para pemilik modal untuk melakukan penilaian saham. Laporan keuangan perusahaan yang berstatus go public sangat dibutuhkan bagi investor yang ingin menanamkan modalnya pada perusahaan tipe ini karena sahamnya dimiliki secara luas dan mempengaruhi apresiasi masyarakat. Pemegang saham akan mengamati hal paling utama dalam laporan yaitu laporan laba rugi serta dividen yang diterima. Para pencari informasi harus melakukan analisis informasi akuntansi.

Laporan keuangan adalah informasi kondisi keuangan suatu perusahaan dan dapat dijadikan sebagai gambaran kinerja perusahaan. Alat utama menganalisis kinerja keuangan perusahaan adalah rasio keuangan. Rasio keuangan adalah alat utama untuk melakukan analisis keuangan dan memiliki beberapa kegunaan (Hery, 2015). Rasio keuangan sebagai media untuk mendapatkan indikasi seperti posisi kas, hutang, dan manajemen serta struktur modal yang sehat.

Rasio yang berhubungan dengan hutang perusahaan adalah rasio solvabilitas, yang digunakan untuk mengukur sejauh mana aktiva perusahaan dibiayai dengan hutang (Kasmir, 2012). Total hutang dibandingkan dengan total modal dapat diartikan sebagai Debt to Equity Ratio (DER), dapat disimpulkan untuk seberapa besar modal yang dijaminkan atas hutang perusahaan. Semakin tinggi nilai DER maka kinerja perusahaan semakin tidak baik karena tingkat resiko kreditor yang semakin tinggi. Kegagalan bisa saja terjadi bagi pihak kreditur dan berhubungan dengan likuiditas perusahaan. Kondisi ini akan mempengaruhi posisi perusahaan dalam pasar, sehingga berdampak pada penilaian, permintaan, dan penawaran.

Kondisi perusahaan di pasar dapat dianalisis dengan rasio nilai pasar (profitabilitas). Fokus utama para pemegang saham adalah keuntungan yang diperoleh melalui kepemilikan saham. Earning Per Share (EPS) adalah rasio yang mencerminkan kemampuan perusahaan dalam menghasilkan laba untuk setiap lembar saham yang beredar (Darmadji, 2012). Semakin besar angka EPS maka semakin besar laba yang didapatkan pemegang saham.

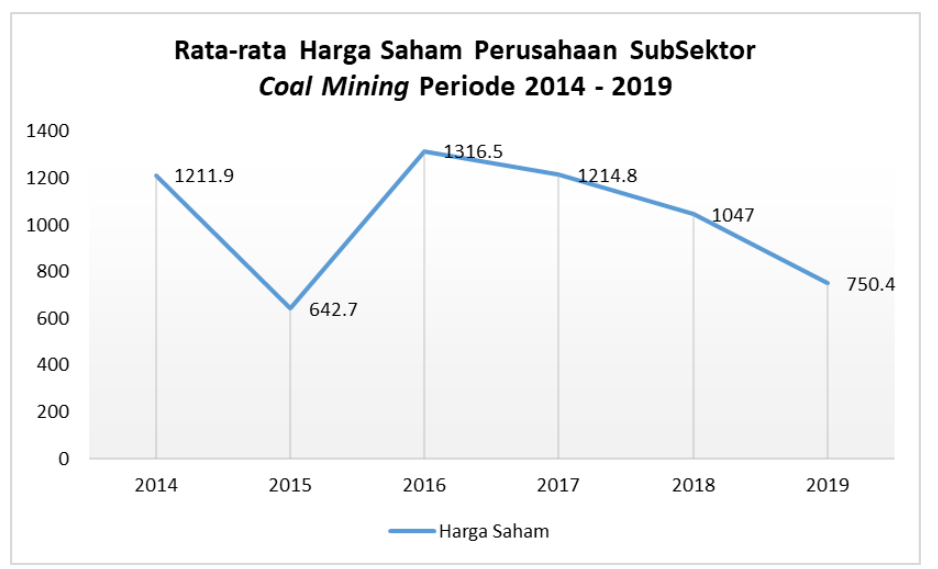

Grafik 1. Rata-rata Harga Saham Perusahaan Batubara 2014-2019 
Sumber: Data Diolah Penulis 2020

Tabel 1

Daftar Perusahaan yang Menjadi Sampel Penelitian

\begin{tabular}{|c|l|c|}
\hline No & \multicolumn{1}{|c|}{ Nama Perusahaan } & Kode \\
\hline 1 & PT. Petrosea Tbk. & PTRO \\
\hline 2 & PT. Adaro Energy Tbk. & ADRO \\
\hline 3 & PT. Surya Esa Perkasa Tbk. & ESSA \\
\hline 4 & PT. Elnusa Tbk. & ELSA \\
\hline 5 & PT. Timah (Persero) Tbk. & TINS \\
\hline 6 & PT. Toba Bara Sejahtra Tbk. & TOBA \\
\hline 7 & PT. Golden Energy Mines Tbk. & GEMS \\
\hline 8 & PT. Harum Energy Tbk. & HRUM \\
\hline 9 & $\begin{array}{l}\text { PT. Resource Alam Indonesia } \\
\text { Tbk. }\end{array}$ & KKGI \\
\hline 10 & $\begin{array}{l}\text { PT. Perdana Karya Perkasa } \\
\text { Tbk. }\end{array}$ & PKPK \\
\hline
\end{tabular}

Sumber: Data Diolah Penulis 2020

Pada Grafik 1, rata-rata harga saham pada subsektor pertambangan yang terdaftar pada Bursa Efek Indonesia (BEI) mengalami kenaikan dan penurunan. Pada tahun 2014 menuju tahun 2015 terdapat penurunan cukup signifikan, kemudian di tahun 2016 mengalami kenaikan drastis. Namun sejak 2016 sampai tahun 2019, harga saham mengalami penurunan secara terus-menerus. Fluktuasi harga saham yang terjadi dipengaruhi oleh beberapa faktor, salah satunya adalah faktor internal yang sebenarnya dapat dikendalikan oleh perusahaan. Di antaranya adalah Debt to Equity Ratio (DER) dan Earning Per Share (EPS).

Debt to Equity Ratio (DER), Earning Per Share (EPS), dan Harga Saham adalah variabel independen dan dependen dalam penelitian ini. Dengan metode deskriptif dan metode verifikatif, diharapkan analisis ini dapat bermanfaat baik secara teoritis maupun praktis untuk mengetahui seberapa besar pengaruh dari Debt to Equity Ratio (DER) dan Earning Per Share (EPS) terhadap harga saham. Gambaran masalah yang dapat dituangkan dalam penelitian ini adalah:

1. Apakah Debt to Equity Ratio (DER) berpengaruh terhadap harga saham pada perusahaan subsektor pertambangan batubara (coal mining) periode tahun 2014 - 2019?

2. Apakah Earning Per Share (EPS) berpengaruh terhadap harga saham pada perusahaan subsektor pertambangan batubara (coal mining) periode tahun $2014-2019$ ?

3. Apakah Debt to Equity Ratio (DER) dan Earning Per Share (EPS) secara bersamaan berpengaruh terhadap harga saham pada perusahaan subsektor pertambangan batubara (coal mining) periode tahun $2014-2019 ?$ 


\section{Akuntansi Keuangan}

Akuntansi keuangan adalah satu ilmu dalam bidang akuntansi yang memiliki tiga proses utama yaitu identifikasi, pencatatan, dan pengkomunikasian kejadian yang terjadi untuk pihak yang berkepentingan dalam bentuk laporan akuntansi dan disebut sebagai laporan keuangan. Akuntansi keuangan adalah ilmu akuntansi yang berfungsi menjalankan semua proses akuntansi hingga membuahkan informasi keuangan untuk pihak eksternal. (Rudianto, 2012).

\section{Laporan Keuangan}

Laporan keuangan merupakan hasil kegiatan proses akuntansi yang dirangka dan didasari prinsipprinsip akuntansi oleh pihak perusahaan. Laporan keuangan adalah intisari suatu proses pencatatan, terdiri dari ringkasan dari transaksi-transaksi keuangan yang terjadi selama tahun buku yang bersangkutan (Baridwan, 2010). Penyusunan laporan keuangan dilakukan manajemen untuk bertanggung jawab atas kewajibannya kepada para pemilik perusahaan. Ada lima alat dari laporan keuangan ialah neraca, laporan laba rugi, laporan perubahan modal, laporan arus kas, dan catatan atas laporan keuangan (Kasmir, 2012).

\section{Debt to Equity Ratio (DER)}

Debt to Equity Ratio (DER) adalah salah satu rasio solvabilitas. Debt to Equity Ratio (DER) adalah rasio yang digunakan untuk menilai hutang dengan ekuitas dan ditemukan dengan cara seluruh hutang termasuk hutang lancar dibandingkan dengan seluruh ekuitas (Kasmir, 2012). Rasio ini disediakan untuk mengetahui jumlah uang yang diberikan peminjam (kreditor) kepada pemilik perusahaan. Rasio ini dipakai untuk membandingkan total hutang dan modal, dengan aktiva yang dibiayai dari hutang. Semakin tinggi angka DER maka semakin rendah harga saham (berpengaruh negatif), sedangkan semakin rendah angka DER maka semakin tinggi harga saham karena perusahaan harus membayar hutang dan investor semakin tidak menarik untuk membeli saham perusahaan.

H1: Debt to Equity Ratio (DER) berpengaruh terhadap harga saham

\section{Earning Per Share (EPS)}

Variabel ini adalah satu dari rasio nilai pasar. Earning Per Share (EPS) merupakan rasio keberhasilan manajemen perusahaan dalam memberikan keuntungan bagi pemegang saham biasa (Hery, 2015). Rasio ini menampilkan keterkaitan total laba bersih dengan bagian dari pemilik pemegang saham dalam perusahaan. Semakin tinggi nilai EPS maka semakin tinggi laba diperoleh dari per lembar saham yang diberikan kepada para pemegang saham.

H2: Earning Per Share (EPS) berpengaruh terhadap harga saham

\section{Harga Saham}


Saham merupakan salah satu alat di pasar modal yang sangat diminati karena memberikan tingkat pengembalian yang sangat menguntungkan. Saham merupakan satu lembar kertas yang tertera jelas nilai harga, nama perusahaan investor, diikuti bersama pemberitahuan hak dan kewajiban kepada setiap pemegangnya. Saham merupakan surat bukti kepemilikan perusahaan atau penyertaan pada perusahaan yang terbentuk Perusahaan Terbatas (Sutrisno, 2012). Saham (stock) adalah tanda penyertaan/kepemilikan seseorang atau badan dalam suatu perusahaan atau perseroan terbatas (Darmadji, 2012). Nama pemilik saham tertulis dalam saham yang dibeli dari perusahaan yang menerbitkan surat berharga.

H3: Debt to Equity Ratio (DER) dan Earning Per Share (EPS) berpengaruh secara bersama-sama terhadap harga saham

\section{METODE}

Metode analisis data adalah kegiatan setelah data dari seluruh responden atau sumber data lain terkumpul. Metode penelitian ini menggunakan metode deskriptif dan verifikatif melalui teknik purposive sampling. Purposive sampling adalah teknik penentuan sampel dengan kriteria tertentu (Sugiyono, 2017). Kriteria tersebut ialah: (1) Perusahaan subsektor pertambangan batubara yang terdaftar di Bursa Efek Indonesia (BEI) periode tahun 2014 - 2019. (2) Perusahaan mempublikasikan laporan keuangan di Indonesia Capital Market Directory (ICMD) selama periode 2014 - 2019. (3) Perusahaan menyajikan laporan keuangan tahunan periode pengamatan tahun 2014 - 2019. (4) Perusahaan memiliki kelengkapan data yang diperlukan dalam penelitian sesuai dengan variabel yang diteliti yaitu Debt to Equity Ratio (DER), Earning Per Share (EPS), dan harga saham. Variabel independen (bebas) akan diberi tanda (X) dan variabel dependen (terikat) akan diberi tanda (Y) yaitu harga saham.

Analisis deskriptif statistik difungsikan untuk menganalisis data dengan mendeskripsi atau menggambarkan data yang telah terkumpul (Sugiyono, 2017). Sedangkan metode verifikatif bertujuan untuk mengetahui hubungan keeratan antar variabel melalui perhitungan statistik sehingga dihasilkan pembuktian yang menunjukkan hipotesis ditolak atau diterima (Nadzir, 2011). Metode penelitian verifikatif difungsikan untuk membuktikan suatu hipotesis yang sumber datanya diperoleh di lapangan.

Data primer diperoleh dari pihak kedua, yaitu laporan keuangan perusahaan yang dapat diunduh melalui website resmi IDX (Indonesia Stock Exchange). Penelitian ini melibatkan populasi dari perusahaanperusahaan subsektor pertambangan batubara yang terdaftar di Bursa Efek Indonesia (BEI) periode tahun 2014 - 2019. Dari 47 perusahaan, sebanyak 10 perusahaan menjadi sampel berdasarkan kriteria-kriteria yang sudah ditentukan sebelumnya.

Metode yang digunakan adalah metode kuantitatif, yaitu data berupa angka yang diambil dari laporan keuangan perusahaan subsektor batubara yang menjadi sampel. Datanya akan dianalisis menggunakan statistik deskriptif yang akan menampilkan nilai-nilai range, minimum, maksimum, rata-rata, dan standar deviasi. Kemudian dilakukan uji asumsi klasik mencakup uji normalitas, uji multikolineritas, uji autokorelasi, dan uji heteroskedastisitas. Apabila nilai signifikansi > 0,05 maka data dapat dikatakan berdistribusi normal. Pengujian multikolineritas menggunakan perbandingan nilai tolerance $>10 \%(0,1)$ 
dan nilai VIF < 10. Pengujian heteroskedasititas dilakukan dengan melihat diagram Scatterplot dengan ketentuan titik-titik tidak membentuk pola khusus dan menyebar. Pengujian autokorelasi dilakukan dengan nilai Durbin-Watson.

Analisis parsial dan analisis verifikatif adalah metode analisis dalam penelitian ini. Analisis parsial difungsikan untuk mengetahui pengaruh masing-masing variabel independen secara parsial terhadap variabel dependen. Analisis parsial dilakukan dengan metode analisis regresi linear sederhana. Sedangkan analisis verifikatif adalah analisis yang difungsikan untuk mengetahui apakah seluruh variabel independen berpengaruh terhadap variabel dependen. Analisis verifikatif menggunakan metode regresi linear berganda, analisis korelasi berganda, dan analisis determinasi. Uji hipotesis dalam penelitian ini dilakukan dengan uji $\mathrm{t}$ (uji parsial) dan uji $\mathrm{F}$ (uji simultan), membandingkan nilai t-tabel dan f-tabel. Seluruh proses pengolahan data menggunakan software SPSS for Windows 25.

\section{HASIL DAN PEMBAHASAN}

\section{Statistik Deskriptif}

Tabel 2. Analisis Statistik Deskriptif

\begin{tabular}{|l|c|r|r|r|r|r|}
\hline \multicolumn{7}{|c|}{ Descriptive Statistics } \\
\hline & $\mathrm{N}$ & Range & Minimum & Maximum & Mean & $\begin{array}{c}\text { Std. } \\
\text { Deviation }\end{array}$ \\
\hline DER & 60 & 2,89 &, 11 & 3 &, 94817 &, 67622 \\
\hline EPS & 60 & 539,05 & $-105,69$ & 433,36 & 68,83183 & 100,684597 \\
\hline HARGA SAHAM & 60 & 2.945 & 50 & 2.995 & $1.030,55$ & 796,441267 \\
\hline Valid N (listwise) & 60 & & & & & \\
\hline
\end{tabular}

Sumber: SPSS for Windows 25, Data Diolah Penulis 2020

Setelah melalui proses pengolahan data pada Tabel 2, berikut adalah output analisis deskriptif yang diperoleh. Pertama dari Debt to Equity Ratio (DER) sebagai variabel $\mathrm{X}_{1}$ memperoleh angka range rentang nilai sebesar 2,89 dengan nilai minimum sebesar 0,11 dan nilai maksimum sebesar 3. Angka DER terendah dimiliki oleh PT. Harum Energy Tbk. pada tahun 2015, sedangkan angka DER tertinggi dimiliki oleh PT. Perdana Karya Perkasa Tbk. pada tahun 2019. Nilai rata-rata dari 60 data penelitian untuk DER sebesar 0,94817 dan angka standar deviasi sebesar 0,67622. 
Kedua adalah Earning Per Share (EPS) sebagai variabel $\mathrm{X}_{2}$ memperoleh angka range rentang nilai sebesar 539,05 dengan nilai minimum sebesar -105,69 dan nilai maksimum sebesar 433,36 yang dimiliki oleh PT. Petrosea Tbk. Angka EPS terendah dimiliki pada tahun 2016 dan angka tertinggi dimiliki pada tahun 2019. Nilai rata-rata dari 60 data penelitian untuk EPS sebesar 68,83183 dan angka standar deviasi sebesar 100,684597.

Ketiga adalah harga saham sebagai variabel Y. Variabel ini memperoleh angka range rentang nilai sebesar 2.945 dengan nilai minimum sebesar 50 dan nilai maksimum sebesar 2.995. Angka harga saham terendah dimiliki oleh PT. Perdana Karya Perkasa Tbk. pada tahun 2015, 2016, dan 2019. Sedangkan angka harga saham tertinggi dimiliki oleh PT. Surya Esa Perkasa Tbk. pada tahun 2014. Nilai rata-rata dari 60 data penelitian untuk harga saham sebesar 1.030,55 dan angka standar deviasi sebesar 796,441267.

\section{Uji Asumsi Klasik}

a. Uji Normalitas

Uji normalitas dilakukan untuk mengetahui distribusi data dalam variabel yang akan digunakan. Data yang baik dan layak berdistribusi normal baru dapat digunakan untuk melakukan analisis selanjutnya.

Tabel 3. Hasil Uji Normalitas

\begin{tabular}{|c|c|c|}
\hline \multicolumn{3}{|c|}{ One-Sample Kolmogorov-Smirnov Test } \\
\hline & & $\begin{array}{l}\text { Unstandardized } \\
\text { Residual }\end{array}$ \\
\hline \multicolumn{2}{|l|}{$\mathrm{N}$} & 60 \\
\hline \multirow[t]{2}{*}{ Normal Parameters ${ }^{\mathrm{a}, \mathrm{b}}$} & Mean & ,0000000 \\
\hline & Std. Deviation & 632,23738984 \\
\hline \multirow{3}{*}{$\begin{array}{l}\text { Most Extreme } \\
\text { Differences }\end{array}$} & Absolute & , 101 \\
\hline & Positive &, 101 \\
\hline & Negative &,- 061 \\
\hline \multicolumn{2}{|l|}{ Test Statistic } &, 101 \\
\hline \multicolumn{2}{|l|}{ Asymp. Sig. (2-tailed) } &, $198^{c}$ \\
\hline \multicolumn{3}{|c|}{ a. Test distribution is Normal. } \\
\hline \multicolumn{3}{|c|}{ b. Calculated from data. } \\
\hline \multicolumn{3}{|c|}{ c. Lilliefors Significance Correction. } \\
\hline
\end{tabular}

Sumber: SPSS for Windows 25, Data Diolah Penulis 2020

Berdasarkan hasil yang diperoleh pada Tabel 3, output uji normalitas dengan KolmogorovSmirnov Test menunjukkan angka signifikasi atau Asymp. Sig. (2-tailed) atas variabel $\mathrm{X}_{1}$ (Debt to Equity Ratio/DER), $\mathrm{X}_{2}$ (Earning Per Share/EPS), dan Y (Harga Saham) sebesar 0,198. Hal ini menunjukkan bahwa 0,198 >0,05 dan dapat diasumsikan bahwa seluruh data dalam penelitian ini berdistribusi normal. 


\section{b. Uji Multikolineritas}

Uji multikolineritas dilakukan untuk menguji beberapa variabel independen yang kemungkinan saling berkorelasi. Untuk hasil yang baik adalah variabel independen memiliki hubungan dengan variabel dependen, namun tidak saling berhubungan antar variabel bebas.

Tabel 4. Hasil Uji Multikolineritas

\begin{tabular}{|c|c|c|c|c|c|c|c|c|}
\hline \multicolumn{9}{|c|}{ Coefficients $^{\mathbf{a}}$} \\
\hline \multirow{2}{*}{\multicolumn{2}{|c|}{ Model }} & \multicolumn{2}{|c|}{$\begin{array}{c}\text { Unstandardized } \\
\text { Coefficients }\end{array}$} & \multirow{2}{*}{$\begin{array}{c}\text { Standardized } \\
\text { Coefficients }\end{array}$} & \multirow[b]{2}{*}{$\mathrm{T}$} & \multirow[b]{2}{*}{ Sig. } & \multicolumn{2}{|c|}{$\begin{array}{c}\text { Collinearity } \\
\text { Statistics }\end{array}$} \\
\hline & & $\mathrm{B}$ & Std. Error & & & & Tolerance & VIF \\
\hline \multirow[t]{3}{*}{1} & (Constant) & 652,257 & 105,983 & & 6,154 &, 000 & & \\
\hline & DER & $-539,039$ & 239,171 &,- 237 & $-2,254$ & ,028 & ,999 & 1,001 \\
\hline & EPS & 4,380 &, 832 &, 554 & 5,264 & ,000 & ,999 & 1,001 \\
\hline
\end{tabular}

Sumber: SPSS for Windows 25, Data Diolah Penulis 2020

Berdasarkan hasil yang diperoleh pada tabel 4, menunjukkan bahwa variabel DER dan EPS memiliki nilai tolerance masing-masing sebesar 1,001 berikut juga dengan nilai VIF yang sama besarnya. Dengan nilai itu, kedua variabel bebas memenuhi ketentuan multikolineritas karena nilai tolerance $0,999>10 \%(0,1)$ dan nilai VIF $1,001<10$, maka model regresi dalam penelitian ini tidak ada multikolineritas antar variabel bebas.

\section{c. Uji Autokorelasi}

Model regresi yang digunakan adalah model efek tetap, maka tidak perlu mengasumsikan bahwa komponen gangguan tidak berkorelasi dengan variabel independen (X) yang akan sulit untuk dipenuhi. Sehingga uji autokorelasi dapat diabaikan dalam penelitian ini. Model regresi yang baik adalah yang bebas dari masalah autokorelasi. Pengujian ini dilakukan dengan melihat angka Tabel Durbin-Watson. Cara melihat nilai dL dan dU dalam tabel Durbin Watson adalah dengan melihat jumlah sampel (n) sebesar 60 dan jumlah variabel independen (k) sebanyak 2. Diperoleh nilai dL sebesar 1,5144 dan nilai dU sebesar 1,6518.

Tabel 5. Hasil Uji Autokorelasi

\begin{tabular}{|l|c|r|r|r|r|}
\hline \multicolumn{7}{|c|}{ Model Summary $^{\mathbf{b}}$} \\
\hline Model & $\mathrm{R}$ & R Square & $\begin{array}{c}\text { Adjusted } \\
\text { R Square }\end{array}$ & $\begin{array}{l}\text { Std. Error of } \\
\text { the Estimate }\end{array}$ & Durbin-Watson \\
\hline 1 &, $608^{\mathrm{a}}$ &, 370 &, 348 & 643,233647 & 1,740 \\
\hline a. Predictors: (Constant), EPS, DER \\
\hline b. Dependent Variable: HARGA SAHAM \\
Sumber: SPSS for Windows 25, Data Diolah Penulis 2020
\end{tabular}

Sumber: SPSS for Windows 25, Data Diolah Penulis 2020 
Berdasarkan hasil yang diperoleh pada Tabel 5, menunjukkan bahwa nilai Asymp. Sig. (2tailed) sebesar 1,740. Hasil tersebut diartikan bahwa 1,740 < 1,5144 (d < dL) 159 serta 1,740 < 1,6518 $(\mathrm{d}<\mathrm{dU})$. Maka dapat disimpulkan hasil tersebut memenuhi syarat pengambilan keputusan dengan tabel Durbin Watson $0<\mathrm{d}<\mathrm{d} 1 / \mathrm{dL}$ (lihat tabel 5) sehingga model regresi dalam penelitian ini tidak ada autokorelasi positif.

\section{d. Uji Heteroskedastisitas}

Uji heteroskedastisitas digunakan untuk mencari tahu ketidaksamaan varians dari residual satu pengamatan ke pengamatan lain, yang baik adalah tidak terjadi heteroskedastisitas (homoskedastisitas). Pengambilan keputusan dalam uji ini adalah bila terbentuk pola tertentu atas titik-titik yang muncul pada grafik scatterplot (bergelombang, melebar, dan kemudian menyempit). Hal ini akan mengindikasikan telah terjadi heteroskedastisitas. Bila terbentuk pola yang tidak jelas serta titik-titik menyebar pada sumbu Y, maka dapat dikatakan tidak terjadi heteroskedastisitas.

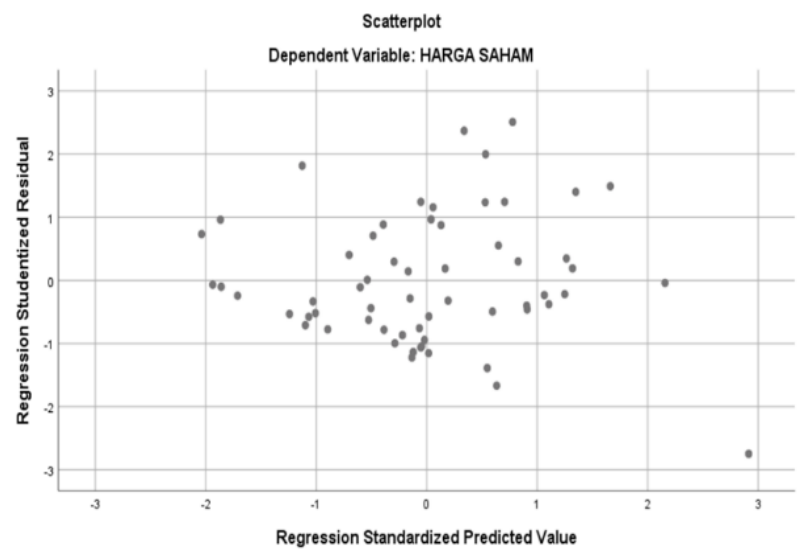

Grafik 2. Hasil Uji Heteroskedastisitas

Sumber: SPSS for Windows 25, Data Diolah Penulis 2020

Berdasarkan hasil yang diperoleh pada Grafik 2, menunjukkan bahwa diperoleh gambar Scatterplot yang terdapat titik-titik yang memiliki pola tidak jelas. Serta titik-titik tersebut berada di atas dan di bawah angka 0 pada sumbu Y. Sehingga disimpulkan bahwa data dalam penelitian ini bebas dari gejala heteroskedastisitas.

\section{Analisis Parsial}

Analisis parsial digunakan untuk mengetahui hubungan antara variabel dependen dan independen secara parsial, yaitu antara $\mathrm{X}_{1} \mathrm{Y}$ dan $\mathrm{X}_{2} \mathrm{Y}$ menggunakan analisis regresi linear sederhana.

Tabel 6. Hasil Analisis Parsial $\mathrm{X}_{1} \mathrm{Y}$

\section{Coefficients $^{\mathrm{a}}$}




\begin{tabular}{|c|c|c|c|c|c|c|}
\hline \multirow{2}{*}{\multicolumn{2}{|c|}{ Model }} & \multicolumn{2}{|c|}{$\begin{array}{l}\text { Unstandardized } \\
\text { Coefficients }\end{array}$} & \multirow{2}{*}{$\begin{array}{c}\text { Standardize } \\
\text { d } \\
\text { Coefficients } \\
\text { Beta }\end{array}$} & \multirow[b]{2}{*}{$\mathrm{T}$} & \multirow[b]{2}{*}{ Sig. } \\
\hline & & B & $\begin{array}{l}\text { Std. } \\
\text { Error }\end{array}$ & & & \\
\hline \multirow[t]{2}{*}{1} & (Constant) & 948,927 & 108,476 & & 8,748 & ,000 \\
\hline & DER & - & 288,943 &,- 252 & $-1,982$ & ,052 \\
\hline \multicolumn{7}{|c|}{ a. Dependent Variable: HARGA SAHAM } \\
\hline
\end{tabular}

Tabel 7. Hasil Analisis Parsial $\mathrm{X}_{2} \mathrm{Y}$

\begin{tabular}{|c|c|c|c|c|c|c|}
\hline \multicolumn{7}{|c|}{ Coefficients $^{\mathbf{a}}$} \\
\hline \multirow{2}{*}{\multicolumn{2}{|c|}{ Model }} & \multicolumn{2}{|c|}{$\begin{array}{c}\text { Unstandardized } \\
\text { Coefficients }\end{array}$} & $\begin{array}{c}\text { Standardize } \\
\mathrm{d} \\
\text { Coefficients }\end{array}$ & \multirow[b]{2}{*}{$\mathrm{t}$} & \multirow[b]{2}{*}{ Sig. } \\
\hline & & B & $\begin{array}{l}\text { Std. } \\
\text { Error }\end{array}$ & Beta & & \\
\hline \multirow[t]{2}{*}{1} & (Constant) & 725,603 & 104,350 & & 6,954 & ,000 \\
\hline & EPS & 4,430 &, 860 &, 560 & 5,149 &, 000 \\
\hline
\end{tabular}

Sumber: SPSS for Windows 25, Data Diolah Penulis 2020

Berdasarkan hasil yang diperoleh dari analisis parsial $\mathrm{X}_{1} \mathrm{Y}$ pada Tabel 6 , menunjukkan angka signifikansi sebesar 0,052 >0,05 sehingga disimpulkan bahwa Debt to Equity Ratio (DER) secara parsial tidak berpengaruh terhadap harga saham.

Kemudian hasil dari analisis parsial $\mathrm{X}_{2} \mathrm{Y}$ pada Tabel 7, menunjukkan angka signifikansi sebesar $0,000<0,05$ sehingga disimpulkan bahwa Earning Per Share (EPS) berpengaruh secara parsial terhadap harga saham.

\section{Analisis Regresi Linear Berganda}

Tabel 8. Hasil Analisis Regresi Linear Berganda

\begin{tabular}{|c|c|c|c|c|c|c|}
\hline \multicolumn{7}{|c|}{ Coefficients $^{\mathbf{a}}$} \\
\hline \multirow{2}{*}{\multicolumn{2}{|c|}{ Model }} & \multicolumn{2}{|c|}{$\begin{array}{l}\text { Unstandardized } \\
\text { Coefficients }\end{array}$} & \multirow{2}{*}{$\begin{array}{c}\begin{array}{c}\text { Standardized } \\
\text { Coefficients }\end{array} \\
\text { Beta } \\
\end{array}$} & \multirow[b]{2}{*}{$\mathrm{t}$} & \multirow[b]{2}{*}{ Sig. } \\
\hline & & $\mathrm{B}$ & Std. Error & & & \\
\hline \multirow[t]{3}{*}{1} & (Constant) & 652,257 & 105,983 & & 6,154 & ,000 \\
\hline & DER & $-539,039$ & 239,171 &,- 237 & $-2,254$ & ,028 \\
\hline & EPS & 4,380 & 832 &, 554 & 5,264 & ,000 \\
\hline
\end{tabular}


a. Dependent Variable: HARGA SAHAM

Sumber: SPSS for Windows 25, Data Diolah Penulis 2020

Berdasarkan hasil yang diperoleh pada Tabel 8, didapatkan persamaan regresi sebagai berikut:

$$
\mathrm{Y}=652,257-539,039 \mathrm{X}_{1}+4,380 \mathrm{X}_{2}
$$

Konstanta (a) sebesar 652,257 menyatakan bahwa jika DER dan EPS berpengaruh, harga saham menjadi 652,257. Koefisien regresi $\mathrm{X}_{1}$ sebesar $-539,039$ menunjukkan bahwa setiap variabel DER naik 1 satuan, maka harga saham akan menurun sebesar 539,039 dengan asumsi variabel lain konstan. Koefisien regresi $\mathrm{X}_{2}$ sebesar 4,380 menunjukkan bahwa setiap variabel EPS naik 1 satuan, maka harga saham akan bertambah 4,380 dengan alasan variabel lain konstan. Jika harga saham naik 1 satuan, maka DER akan turun sebesar -539,039 dan EPS akan naik 4,380. Secara parsial melalui analisis regresi linear berganda, Debt to Equity Ratio/ $\mathrm{X}_{1}$ berpengaruh terhadap harga saham (Y) karena nilai signifikansinya $0,028<0,05$ sedangkan Earning Per Share/ $\mathrm{X}_{2}$ berpengaruh terhadap harga saham (Y) karena nilai signifikansinya $0,000<0,05$.

\section{Analisis Korelasi Berganda}

Analisis korelasi berganda difungsikan untuk mengasumsikan hasil derajat atau kekuatan hubungan secara bersama-sama antara seluruh variabel $\mathrm{X}$ terhadap variabel $\mathrm{Y}$.

Tabel 9. Hasil Analisis Regresi Linear Berganda

\begin{tabular}{|l|c|c|c|c|}
\hline \multicolumn{5}{|c|}{ Model Summary $^{\mathbf{b}}$} \\
\hline Model & $\mathrm{R}$ & $\begin{array}{c}\mathrm{R} \\
\text { Square }\end{array}$ & $\begin{array}{c}\text { Adjusted R } \\
\text { Square }\end{array}$ & $\begin{array}{c}\text { Std. Error of the } \\
\text { Estimate }\end{array}$ \\
\hline 1 &, $608^{\mathrm{a}}$ &, 370 &, 348 & 643,233647 \\
\hline \multicolumn{2}{|l}{ a. Predictors: (Constant), EPS, DER } \\
\multicolumn{4}{|l}{ b. Dependent Variable: HARGA SAHAM } \\
\hline
\end{tabular}

Sumber: SPSS for Windows 25, Data Diolah Penulis 2020

Berdasarkan hasil yang diperoleh pada Tabel 9, dapat disimpulkan bahwa nilai koefisien $\mathrm{R}$ sebesar 0,608. Hal tersebut menunjukkan bahwa Debt to Equity Ratio (DER) dan Earning Per Share (EPS) terhadap harga saham memiliki keterikatan hubungan yang kuat. Sesuai dengan kelompok keeratan korelasi:
a. $0,0-0,2=$ Korelasi sangat lemah
b. 0,21-0,42 = Korelasi lemah
c. $0,41-0,72=$ Korelasi kuat
d. $0,71-0,92=$ Korelasi sangat kuat
e. $0,91-0,99=$ Korelasi kuat sekali
f. 1 = Korelasi Sempurna 


\section{Analisis Determinasi}

Koefisien determinasi adalah rasio kesalahan pencocokan terhadap garis regresi terbaik yang disebabkan oleh penggunaan Y rata-rata. Analisis determinasi dapat dilakukan dengan melihat tabel output Model Summary pada bagian R Square di Tabel 8. R Square memperoleh angka sebesar 0,370 atau 37\%. Hal tersebut menunjukkan bahwa Debt to Equity Ratio/DER $\left(\mathrm{X}_{1}\right)$ dan Earning Per Share/EPS $\left(\mathrm{X}_{2}\right)$ mampu menjelaskan variabel harga saham selaku variabel terikat sebesar 37\%, sedangkan sisanya sebesar 63\% dijelaskan oleh variabel lain yang tidak ada dalam penelitian.

Untuk angka sumbangan masing-masing variabel dapat digunakan rumus perhitungan Sumbangan Efektif (SE) dan Sumbangan Relatif (SR). Dibutuhkan nilai koefisien Standardized Coefficients B yang terdapat pada output tabel Coefficients ${ }^{\mathrm{a}}$ dalam model regresi, koefisien $\mathrm{R}_{\mathrm{xy}}$ dalam output Correlations Pearson, dan determinasi.

Tabel 10. Konstanta Perhitungan SE dan SR

\begin{tabular}{|c|c|c|c|c|}
\hline No & Variabel & $\mathbf{B}$ & $\mathbf{R}_{\mathbf{x y}}$ & $\mathbf{R}^{\mathbf{2}}$ \\
\hline 1 & $\begin{array}{c}\text { Debt to Equity } \\
\text { Ratio/DER }\end{array}$ & $-0,237$ & $-0,252$ & $37 \%$ \\
\hline 2 & Earning Per Share/EPS & 0,554 & 0,560 & $37 \%$ \\
\hline
\end{tabular}

Sumber: SPSS for Windows 25, Data Diolah Penulis 2020

$$
\begin{gathered}
S E\left(X_{n}\right) \%=\beta\left(X_{n}\right) \times R_{x y} \times 100 \% \\
\operatorname{SR}\left(X_{n}\right) \%=\frac{\mathrm{SE}\left(X_{n}\right) \%}{R^{2}}
\end{gathered}
$$

Berdasarkan hasil perhitungan, sumbangan efektif (SE), 6\% analisis dipengaruhi oleh Debt to Equity Ratio/DER terhadap harga saham. Sementara dominasi Earning Per Share/EPS terhadap harga saham adalah 31\%. Dapat disimpulkan bahwa Earning Per Share/EPS $\left(\mathrm{X}_{2}\right)$ memiliki pengaruh lebih dominan terhadap variabel $\mathrm{Y}$ daripada Debt to Equity Ratio/DER ( $\left.\mathrm{X}_{1}\right)$. Sedangkan berdasarkan perhitungan sumbangan relatif (SR), Debt to Equity Ratio/DER terhadap harga saham sebesar 16,216\%, sementara Earning Per Share/EPS terhadap harga saham sebesar 83,784\%. Dapat disimpulkan bahwa variabel Earning Per Share/EPS $\left(\mathrm{X}_{2}\right)$ memiliki pengaruh lebih dominan terhadap variabel $\mathrm{Y}$ daripada variabel Debt to Equity Ratio/DER $\left(\mathrm{X}_{1}\right)$. Total keseluruhan sebesar 100\% atau sama dengan 1.

\section{Uji Hipotesis}

\section{a. Uji T}


Tabel 11. Hasil Uji T

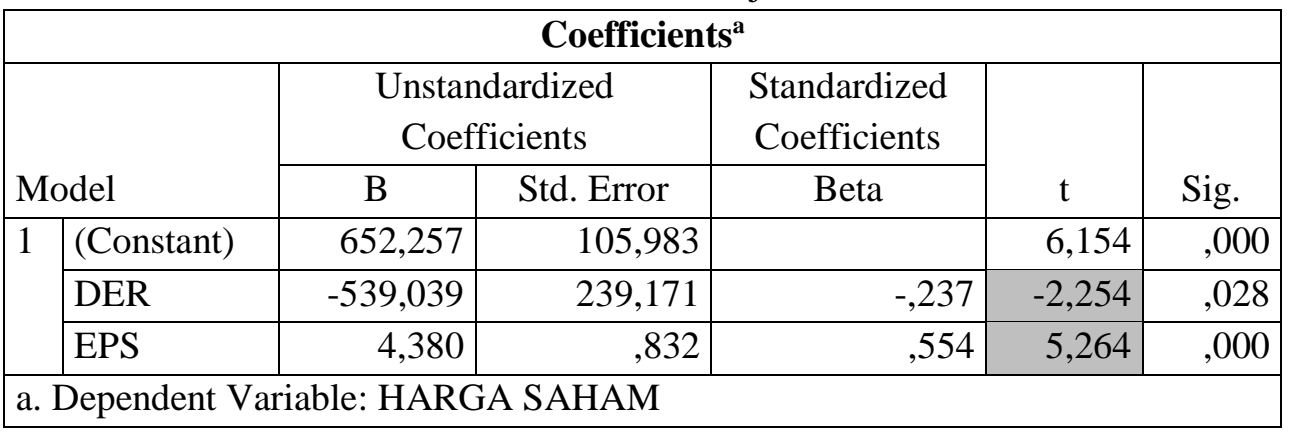

Sumber: SPSS for Windows 25, Data Diolah Penulis 2020

Uji T adalah pengujian dengan membandingkan nilai t-tabel dengan t-hitung. Apabila thitung lebih besar dari t-tabel maka variabel independen secara individual mempengaruhi variabel dependen. Mencari t-tabel dilakukan dengan melakukan selisih antara jumlah data (n), jumlah variabel independen (k), dan dikurangi 1 yang hasilnya sebesar 57. Diperoleh nilai t-tabel dengan signifikansi 0,05 sebesar 2,00247.

Berdasarkan hasil yang diperoleh pada Tabel 11, hasil menunjukkan angka t-hitung pada DER sebesar -2,254; maka t-hitung < t-tabel $(-2,254<2,00247)$. Dapat disimpulkan bahwa hasilnya berada di daerah $\mathrm{H} 1$ ditolak sehingga tidak terdapat pengaruh antara Debt to Equity Ratio/DER $\left(\mathrm{X}_{1}\right)$ terhadap harga saham (Y).

Sedangkan nilai t-hitung yang yang tertera pada tabel di atas sebesar 5,264; maka t-hitung > t-tabel $(5,264>2,00247)$. Dapat disimpulkan bahwa hasilnya berada di daerah $\mathrm{H} 2$ diterima sehingga terdapat pengaruh antara Earning Per Share/EPS $\left(\mathrm{X}_{2}\right)$ terhadap harga saham $(\mathrm{Y})$.

\section{b. Uji F}

Tabel 12. Hasil Uji F

\begin{tabular}{|l|l|r|r|r|c|c|}
\hline \multicolumn{7}{|c|}{ ANOVA $^{\text {a }}$} \\
\hline \multirow{2}{*}{ Model } & Sum of Squares & Df & Mean Square & F & Sig. \\
\hline \multirow{2}{*}{1} & Regression & 13841079,941 & 2 & 6920539,970 & 16,726 &, $000^{\mathrm{b}}$ \\
\cline { 2 - 7 } & Residual & 23583722,909 & 57 & 413749,525 & & \\
\cline { 2 - 7 } & Total & 37424802,850 & 59 & & & \\
\hline
\end{tabular}

Sumber: SPSS for Windows 25, Data Diolah Penulis 2020

Uji $\mathrm{F}$ adalah pengujian dengan membandingkan nilai f-tabel dengan f-hitung. Apabila fhitung > f-tabel maka semua variabel independen secara bersama-sama berpengaruh terhadap variabel dependen. Mencari f-tabel dilakukan dengan V1 = 2 (jumlah variabel independen) dan V2 adalah selisih antara jumlah data (n) dengan jumlah variabel independen (k), diperoleh nilai f-tabel sebesar 58. Kemudian setelah diolah, diperoleh nilai t-tabel dengan signifikansi 0,05 sebesar 3,16. 
Berdasarkan hasil yang diperoleh pada Tabel 12, f-hitung memiliki angka sebesar 16,726 maka f-hitung > f-tabel, yaitu 16,726 > 3,16. Dapat disimpulkan bahwa H3 diterima, berarti Debt to Equity Ratio/DER $\left(\mathrm{X}_{1}\right)$ dan Earning Per Share/EPS $\left(\mathrm{X}_{2}\right)$ secara bersama-sama berpengaruh terhadap harga saham.

\section{PEMBAHASAN}

\section{Pengaruh Debt to Equity Ratio/DER $\left(\mathrm{X}_{1}\right)$ Terhadap Harga Saham}

Berdasarkan hasil pengujian hipotesis menggunakan Uji T dalam model regresi, nilai t-hitung ditemukan sebesar -2,254. Bila dibandingkan dengan nilai t-tabel, maka nilai t-hitung DER lebih kecil dibanding nilai t-tabel, sehingga $-2,254<2,00247$ dengan signifikansi 0,028. Sehingga dapat disimpulkan DER berpengaruh negatif tidak signifikan terhadap harga saham, berarti ada hubungan tidak searah antara nilai dan harga saham. Pengujian juga dilakukan menggunakan metode regresi linear sederhana dengan variabel harga saham sebagai variabel dependen dan DER sebagai variabel independen. Hasil dari analisis menunjukkan bahwa nilai signifikansi diperoleh sebesar 0,052. Bila dibandingkan dengan nilai ketentuan maka 0,052 > 0,05 dan penulis dapat mengasumsikan bahwa H0 diterima. Sehingga tidak terdapat pengaruh antara DER terhadap harga saham.

Penulis berpendapat bahwa tidak berpengaruhnya DER terhadap harga saham dalam penelitian ini disebabkan adanya perusahaan yang tidak solvable pada subsektor ini. Perusahaan dikatakan tidak solvable jika hutang yang dimiliki lebih besar dibanding total asetnya, sehingga perusahaan tidak sanggup untuk memenuhi kewajiban jangka panjangnya. Tidak adanya pengaruh DER terhadap harga saham mengindikasikan bahwa sebagian besar investor mengikuti fluktuasi yang terjadi di pasar saham. Investor lebih mengamati laba jangka pendek (capital gain) dalam mengambil keputusan pembelian saham, investor tidak mempertimbangkan nilai DER perusahaan. Orientasi investor adalah capital gain bukan dividend oriented.

Hasil pengujian ini menunjukkan bahwa informasi perubahan DER yang bisa diperoleh dari laporan keuangan tidak berpengaruh pada keputusan harga saham perusahaan subsektor batubara di pasar modal Indonesia. Investor tidak berfokus terhadap penggunaan hutang serta pengembalian bunga dan pokok hutang yang akhirnya tidak mempengaruhi pemikiran investor terhadap profit di masa depan.

\section{Pengaruh Earning Per Share/EPS $\left(\mathrm{X}_{2}\right)$ Terhadap Harga Saham}

Berdasarkan hasil pengujian hipotesis menggunakan Uji T dalam model regresi, diperoleh nilai t-hitung sebesar 5,264. Bila dibandingkan dengan nilai t-tabel, maka 5,264 > 2,00247 dengan signifikansi 0,000. Sehingga dapat disimpulkan $\mathrm{H} 2$ diterima, terdapat pengaruh antara EPS terhadap harga saham. Pengujian juga dilakukan menggunakan analisis regresi linear parsial dengan variabel harga saham sebagai variabel dependen dan EPS sebagai variabel independen. Hasil analisis menunjukkan bahwa nilai signifikansi diperoleh sebesar 0,000. Bila dibandingkan dengan nilai 
ketentuan maka $0,000<0,05$ dan penulis dapat disimpulkan bahwa $\mathrm{H} 0$ ditolak sehingga terdapat pengaruh antara EPS terhadap harga saham.

Variabel EPS terbukti memberikan hubungan yang positif terhadap harga saham. Pengaruh ini menjelaskan bahwa tingginya angka EPS akan menarik investor karena EPS menandakan bahwa tingginya harga saham akan semakin tinggi keuntungan bagi investor. EPS menjadi penilaian yang sangat penting untuk memperkiraan seberapa potensi yang diterima bila membeli saham tersebut. EPS total jumlah laba/keuntungan yang diperoleh tiap lembar saham dalam suatu periode. EPS adalah gambaran perusahaan mampu menghasilkan keuntungan netto pada setiap lembar sahamnya. Perusahaan yang berhasil menaikkan taraf kemakmuran investor salah satunya dengan meningkatnya nilai EPS. Hal ini mendorong investor menambah investasinya pada perusahaan tersebut, karena meningkatnya jumlah permintaan saham mendorong harga saham naik. Maka dengan meningkatnya nilai EPS, pasar akan merespons positif yang diikuti dengan harga saham yang naik.

3. Pengaruh Debt to Equity Ratio/DER $\left(\mathbf{X}_{1}\right)$ dan Earning Per Share/EPS $\left(\mathbf{X}_{2}\right)$ Terhadap Harga Saham

Berdasarkan hasil pengujian hipotesis menggunakan Uji F dengan model regresi, diperoleh nilai f-hitung sebesar 16,726. Bila dibandingkan maka nilai f-hitung lebih besar dibanding nilai f-tabel, sehingga 16,726 > 3,16 dengan signifikansi 0,000. Sehingga dapat disimpulkan H3 diterima, DER dan EPS secara bersama-sama berpengaruh terhadap harga saham.

Analisis juga menggunakan analisis regresi linear berganda di mana nilai signifikansi diperoleh sebesar 0,000. Bila dibandingkan dengan nilai ketentuan maka $0,000<0,05$. Penulis dapat mengasumsikan bahwa H0 ditolak sehingga DER dan EPS secara bersama-sama berpengaruh terhadap harga saham.

Hasil ini menunjukkan bahwa penelitian terdahulu yang menyatakan bahwa kedua variabel tersebut memiliki pengaruh terhadap variabel dependen dapat dibuktikan. Selain itu, teori yang mendukung bahwa semakin rendah DER dan semakin tinggi EPS akan meningkatkan harga saham dapat dibuktikan. Peristiwa ini dikarenakan DER mencerminkan kinerja perusahaan, tingkat hutang yang tinggi akan mempengaruhi bunga sehingga mengurangi keuntungan. Bila dana ekuitas lebih besar daripada biaya hutangnya, saham perusahaaan akan memiliki daya tarik yang dapat ditawarkan di pasar modal. Permintaan yang semakin besar seiring dengan kinerja perusahaan yang meningkat, maka akan berpengaruh terhadap peningkatan harga saham. Peningkatan permintaan saham yang disebabkan kinerja perusahaan yang semakin baik seperti tingkat hutang yang kecil akan mempengaruhi pendapatan perusahaan. Semakin besarnya laba perusahaan maka semakin tinggi nilai EPS. Semakin tinggi nilai EPS maka semakin mempengaruhi harga saham untuk meningkat, dan semakin besar pula profit yang diperoleh pemegang saham di masa yang akan datang untuk setiap lembar saham biasa. Dapat diartikan bahwa nilai DER berpengaruh negatif terhadap harga saham sedangkan nilai EPS berpengaruh positif terhadap harga saham. 


\section{SIMPULAN}

Berdasarkan penjabaran yang sudah dipaparkan pada hasil dan pembahasan, penelitian pengaruh Debt to Equity Ratio (DER) dan Earning Per Share (EPS) terhadap Harga Saham (studi kasus pada perusahaan sub sektor pertambangan yang terdaftar di bursa efek indonesia periode tahun 2014 - 2019) dapat ditarik kesimpulan sebagai berikut:

1. Hasil penelitian dengan model regresi menunjukkan bahwa Debt to Equity Ratio (DER) tidak berpengaruh terhadap harga saham. Tidak berpengaruhnya variabel Debt to Equity Ratio/DER disebabkan karena perusahaan pada subsektor ini diprediksi tidak solvable. Perusahaan dikatakan tidak solvable jika hutang yang dimiliki lebih besar dibanding total asetnya, sehingga perusahaan tidak sanggup untuk memenuhi kewajiban jangka panjangnya. Tidak adanya pengaruh Debt to Equity Ratio/DER terhadap harga saham dapat diasumsikan bahwa sebagian besar investor mengikuti fluktuasi yang terjadi di pasar saham. Investor berfokus pada laba jangka pendek (capital gain) sehingga dalam mempertimbangkan pembelian saham, investor tidak mempertimbangkan nilai Debt to Equity Ratio/DER.

2. Hasil penelitian dengan model regresi menunjukkan bahwa Earning Per Share (EPS) berpengaruh terhadap harga saham. Pengaruh ini menjelaskan bahwa nilai Earning Per Share/EPS yang tinggi akan menarik investor karena Earning Per Share/EPS menandakan bahwa tingginya harga saham akan semakin tinggi keuntungan bagi investor.

3. Hasil penelitian dengan model regresi menunjukkan bahwa Debt to Equity Ratio/DER dan Earning Per Share (EPS) berpengaruh secara bersama-sama terhadap harga saham. Hasil penelitian ini menunjukkan bahwa ketiga variabel memiliki keterkaitan hubungan. Debt to Equity Ratio (DER) dan Earning Per Share (EPS) mencerminkan kinerja perusahaan karena hutang yang tinggi akan mempengaruhi bunga sehingga mengurangi keuntungan, lalu mengurangi daya tarik di pasar modal. Bila kinerja perusahaan meningkat dengan nilai Debt to Equity Ratio (DER) yang semakin kecil, maka permintaan akan meningkat dan berpengaruh terhadap harga saham. Semakin meningkatnya harga saham maka semakin besar laba yang didapatkan perusahaan. Laba yang semakin besar akan mempengaruhi nilai Earning Per Share (EPS) dalam laporan keuangan. Nilai Earning Per Share (EPS) yang semakin meningkat maka semakin besar pula profit yang diperoleh pemegang saham di masa yang akan datang untuk per lembar saham biasa.

\section{DAFTAR PUSTAKA}

Baridwan, Zaki. 2010. Sistem Akuntansi Penyusunan Prosedur dan Metode. Edisi 5. Yogyakarta: BPPE Darmadji. T dan Henry. M.F. 2012. Pasar Modal di Indonesia: Pendekatan Tanya Jawab. Jakarta: Salemba Empat.

Fahmi Irham. 2012. Analisis Laporan Keuangan. Bandung: Alfabeta.

Hery. 2015. Analisis Laporan Keuangan Pendekatan Rasio Keuangan. Yogyakarta: CAPS

Kasmir. 2012. Analisis Laporan Keuangan. Edisi kesatu. Cetakan Kedelapan. Jakarta: PT. Raja Grafindo Persada.

Nazir, Moh. 2011. Metode Penelitian. Bogor: Penerbit Ghalia Indonesia

Rudianto. 2012. Pengantar Akuntansi Konsep dan Teknik Penyusunan Laporan Keuangan. Jakarta: Erlangga. 
Sugiyono. 2017. Metode Penelitian Kuantitatif Kualitatif dan R\&D. Bandung: Penerbit Alfabeta Sutrisno. 2012. Manajemen Keuangan Teori, Konsep dan Aplikasi. Yogyakarta: Ekonisia. www.idx.co.id (Diakses pada tanggal 28 Februari 2020)

https://www.junaidichaniago.wordpress.com (Diakses pada tanggal 17 April 2020)

https://www.indopremier.com (Diakses pada tanggal 24 Juni 2020) 